\title{
obituary
}

\section{W. H. Morton}

William H. Morton, for seven years Assistant Professor of Geology at Addis Ababa University, Ethiopia, was shot to death by Government troops in Addis Ababa on 10 March 1977, one of the many victims of the current political disturbances in Ethiopia.

Bill Morton graduated from Manchester University and served his apprenticeship with the Geological Survey of Uganda. A field geologist par excellence, he belonged to that select group of British geologists with detailed first-hand knowledge of the remoter parts of East Africa.

In addition to his own research publications, always the fruit of long months of painstaking geological mapping with his colleagues and students, Bill had a very real desire to share his hard-earned geological knowledge with students and teachers throughout the country. He had recently completed a handbook for non-specialists on the rocks, minerals and fossils of Ethiopia, and was awaiting the comments of his colleagues. Its publication may have to await happier times. Of more immediate value to the government of Ethiopia are the geological maps of many parts of the country, including the Addis Ababa region, which Bill and his former students produced with that attention to detail and high degree of intellectual honesty which were amongst his outstanding qualities.

The Afar Triangle has stimulated new concepts in geology which have repercussed far beyond Africa, and Bill Morton made his own contribution to the knowledge of a region that has attracted so many distinguished earth scientists. Starting with a recognition that the tilted fault-blocks bordering the Afar were the result of extension tectonics and not, as previously thought, of folding and decompressive stresses, Bill and his colleagues went on to develop a model of crustal attenuation as part of a continuous process of plate separation. His studies of Afar tectonics, of the age trends of plateau and rift margin volcanics in Ethiopia, and of crustal thinning at rift margins, some of which appeared as seminal papers in Nature, were always conveyed in clear and simple prose, a by-product of his experience as a teacher.

A level-headed and thoughtful person, Bill Morton was a tireless teacher, devoted to his students and immensely concerned with imparting practical and worthwhile knowledge. He was equally at home on the summit of a glaciated volcano as at the bottom of Ethiopia's deepest known pot-hole. Well loved by students and colleageus, he was highly respected by geologists from many countries. In a tragic moment, Ethiopia has lost a man who had devoted his career to her scientific advancement and welfare. His many friends and geological colleagues both inside and outside Ethiopia will remember him with love and professional admiration.

D. Adamson, F. M. Dakin and M. A. J. Williams

\section{Hans-Lukas Teuber}

Hans-Lukas Teuber, Professor of Psychology at M.I.T., was lost on January 4 while swimming off the British Virgin Islands. It is thought likely that he died of heart disease; he was 60 years old. Many in Britain will share the sense of loss, not only because "Luke" (as he became known in later years as he became fully absorbed into the American culture) was an indefatigable traveller and lecturer, but also because of a memorable year as Eastman Visiting Professor at Oxford in 1971-2. His audience and influence were deservedly world-wide.

In later years he was perhaps best known as the father of a distinguished, indeed unique, centre of psychology and brain sciences at M.I.T., to which his devotion was complete and in which his pride was transparent. But it was his earlier highly penetrating and influential analyses of the problems and mechanisms of visual perception, in particular, and of brain function more generally, with which he first made his mark. His early major researches were on the psychological analysis of brain wounds in war veterans, carried out while serving with the U.S. Navy during World War N. This type of research remained a consuming interest until the end, but he contributed a unique and distinctive personal approach to a tradition that had its roots in 19th century neuroology. To that tradition Teuber injected a concern for the importance of certain crucial demands that modern psychological analysis places upon the interpretation of brain function. He was, for example, one of the first to seize upon the importance of the distinction between externally imposed changes in sensory stimulation and those that result from self-initiated movement, which produces a "corollary discharge." He was quick to spot and integrate important modern developments, both technical and intellectual, but these always were seen in a historical context which he viewed with enormous erudition and reverence.

Born in Germany and educated at the French College in Berlin and at the University of Basel, he emigrated to America during the War and received his doctorate in psychology at Harvard in 1947. He claimed that he was accepted as a desirable emigré, when his ship was stopped at Gibraltar, because he was able to converse freely in Latin and Greek with the young inspecting British officer. His father was founder, for the Prussian Academy of Sciences, of a field station for the observation of chimpanzees on Tenerife, whose fame was later assured by the important work of Wolfgang Köhler (The Mentality of Apes) carried out there. This perhaps accounts for Teuber's early interest in problems of visual perception identified by the Gestalt psychologists, and his friendship and admiration for Köhler were life-long.

At Harvard, the story is told, he managed to fail the compulsory German translation because, as a new arrival, he did not know enough English into which to translate the German. But, if so, his command of English soon developed to lofty heights, and he could hold an audience rapt with his eloquent and gently humorous style. In 1947 he joined the faculty of the Bellevue Medical Center of New 
York University, where he remained until 1961, when he became Professor of Psychology at M.I.T. His quickness of repartee was renowned. On one occasion, when chided at a symposium by an impatient participant for his frequent references to 19th century authors, Teuber replied without hesitation that he merely wanted to display his originality. And he took a quiet delight in his skill at improvisation and extemporaneous delivery. When a lecture to a large audience in a playhouse was interrupted by a power cut, he continued his lecture, without undue pause, by using his fingers in front of the emergency lamp to project his slides in the form of shadows on the screen.

His move to M.I.T. was at first somewhat turbulent, perhaps because Teuber had a clear and even uncompromising conception of the type of department of psychology he wished to develop. To it he attracted scientists of great distinction from a variety of

\section{A. T. Phillipson}

Professor A. T. Phillipson, who died suddenly on 10 January at the age of 66 , was the leading figure in the great post-war revival of interest in the function of ruminant animals. He graduated in agriculture at Cambridge, gained his MRCVS at the Royal Veterinary College, London and then returned to Cambridge to show his flair for research in a Ph.D. study of gastric motility in sheep. Subsequently, he led a small wartime group, under Sir Joseph Barcroft, FRS, at the ARC Unit of Animal Physiology, Cambridge. Between 1941 and 1947 Phillipson, with Dr R. A. McAnally, showed that the hitherto neglected volatile fatty acids are the final end products of microbial digestion of carbohydrates and that they are absorbed through the heavily keratinized epithelium of the rumen into the portal blood in quantities which provide a significant proportion of the energy requirements of the host. Such a radical conclusion was not accepted without controversy, yet attempts by others to find an alternative explanation only reinforced the evidence in its favour. In fact in the last thirty years the conclusions made by this small group have formed the basis for much of the subsequent work on ruminant digestion throughout the world and, when they were extended to other components of the diet, such as protein, completely changed our concept of ruminant nutrition and metabolism. It is salutary to remind ourselves that this major advance was based, after a preparatory period in the late 1930's for thought and observation, on a series of simple and elegant ex- disciplines, as well as younger persons whose promise later was fulfilled; the contributions of his colleagues were as important in neuroanatomy and neurophysiology as in experimental psychology. He worked unceasingly to attract funds for their endeavours and to promote a genuinely interdisciplinary atmosphere, warm and paternalistic, in which he and his colleagues could flourish. The M.I.T. department became an almost compulsory stopping-off point in the U.S.A. for scientists from throughout the world with interests in brain function and psychology; they were invariably greeted with great hospitality and kindness, their seminars almost always continuing at the Teubers' home late into the evening, surrounded by a formidable but enthusiastic circle of graduate students.

Ironically, his memorial service was held at M.I.T. on the day on which he was to have received an award given by the Institute to a member of its

periments carried out over the relatively short period of about four or five years.

Moving in 1947 to the Rowett $\mathrm{Re}$ search Institute, of which he became Deputy Director in 1952, Phillipson consolidated the advances made at Cambridge. The years at Aberdeen were marked by special attention to the techniques required for the quantitative assessment of the rumiriant digestive processes. Techniques ranging from microbiology to radiography were brought to bear on microbial fermentation and synthesis, ruminal absorption and metabolism of volatile fatty acids, movements of the forestomachs and the propulsion of food to the intestine. $\mathrm{He}$ was one of the first to emphasise and measure the extent to which urea may be secreted into the rumen to provide a substrate for microbial protein synthesis. In a prophetic mood in 1947 (Vet. Rec, 58(8), 81-85) he had stressed the importance of measuring the amounts of protein and polysaccharide received by the animal in microbia form, of knowing how much starch and protein escapes degradation in the rumen and of assessing the amounts of volatile fatty acids absorbed. In 1977 we are beginning to use such information in evaluating diets.

In addition to his important research, Phillipson wrote a number of lucid reviews outlining the state of knowledge of rumen function, always with exact attributions and a minimum of extrapolation, and pointing the way to further essential investigation. These were required reading for a new generation of animal scientists and must have directed many to the fascination faculty for outstanding accomplishment. The citation described him as "a man who joins the instinct of a penetrating experimenter and the sympathetic experience of a true humanist with the consummate style of a gifted teacher." To these qualities may also be added his warmth, skill and dedication as a promoter of neuropsychology both at home and abroad. He was an insightful, popular, and expansive reviewer at international meetings-even as a helpful translator for foreigners, the duration of his commentaries was apt to exceed, by a considerable amount, that occupied by the original speaker. As tragic as was his death, perhaps he would have preferred it to any alternative that might have prevented him from exercising his indefatigable energies at full strength.

$\mathrm{He}$ is survived by his wife, Marianne, who was a devoted partner throughout his career, and by two sons, Andreas and Christopher.

of the rumen. A remarkably high proportion of the active post-war workers in this field spent time with Phillipson, some to experiment, some just to discuss, but all to be welcomed, involved in his interests and influenced for the future. He travelled a good deal and those he met were also much influenced. In such benign ways, Andrew Phillipson has left a permanent mark on rumen studies. His hallmarks were enthusiasm, wide background knowledge, a preference for direct approaches, accuracy and a habit of being right.

Returning to Cambridge in 1963, Phillipson took the Chair of Veterinary Clinical Studies. Administration and teaching then restricted his opportunities for research, but in these activities he preserved the high standards characteristic of his earlier work. He was chairman of the organising committee of the very successful Third International Symposium on Physiology of Digestion and Metabolism in the Ruminant at Cambridge in 1969.

Phillipson was made FRSE in 1953 and his achievements were recognised by honorary degrees at Copenhagen, Ghent and Edinburgh. In England he received major prizes in agricultural and veterinary fields.

Andrew Phillipson was a charming man whose enthusiasm shone through a diffident manner; an aesthetic, person, especially fond of music, he enjoyed Cambridge and his Fellowship to the full. His family life was extremely happy and the sympathy of many friends, worldwide, will go to Mrs Rachel Phillipson and their three sons.

C. C. Balch 